\title{
Analisis Pola Penyediaan Hjauan Pakan dan Strategi Pengembangan pada Lokasi Kawasan Sapi Perah di J awa Tengah
}

\section{(Analysis Forage Provision Pattem and Development Strategy at Dairy Cattle Development Area in Central J ava)}

\author{
Magrianti $\mathrm{T}^{1}$, Priyono ${ }^{1}$, Priyanto $\mathrm{D}^{2}$ \\ ${ }^{1}$ Pusat Penelitian dan Pengembangan Peternakan, Jl. Raya Pajajaran Kav E59 Bogor 16128 \\ ${ }^{2}$ Balai Penelitian Ternak, Ciawi PO Box 221, Bogor \\ tessa.kemtan@gmail.com
}

\begin{abstract}
Dairy cattle to be able to produce products optimally must be fulfilled in quality and quantity. The forage of livestock has an important role as a source of feed which also determines the quality and production of milk. In fact, forage production is not always continuous throughout the year, especially when entering the dry season. The supply pattern arrangement and the availability of forage will affect the feed supply in the dairy farming area in Central Java. This study aims to analyze the pattern of supply and strategy for developing forage on dairy farms in the location of dairy cattle in Central Java. Census was conducted in 5 active dairy farming cooperatives in Semarang Regency and Boyolali Regency. The results showed that elephant grass was the main source of forage for dairy cattle. Based on the results of the SWOT analysis, in the development of forage, the strategy is directed at continuity of forage production. The proposed strategy is the introduction of forage preservation technologies for agricultural food and waste (silage, amoniase and hay); Acceleration of strengthening quality, material, and extension methods for forage; Utilization of agricultural waste; Coordinating with the relevant office for permits for land use owned by Perhutani; Facilitation from related agencies/institution in improving technology and managerial farmers; Expansion of sustainable forage land areas; Introduction and understanding of the types of quality forage; and optimizing the utilization of cattle waste as compost.
\end{abstract}

Key words: Forage, improvement strategy, dairy cattle

\begin{abstract}
ABSTRAK
Sapi perah supaya dapat menghasilkan produk dengan optimal harus tercukupi kebutuhan pakannya secara kualitas dan kuantitas. Hijauan pakan ternak memegang peranan penting sebagai sumber pakan yang turut menentukan kualitas dan produksi susu. Penelitian ini bertujuan untuk menganalisis pola penyediaan dan strategi pengembangan hijauan pakan pada peternakan sapi perah di lokasi kawasan sapi perah di Jawa Tengah. Pengamatan dilakukan pada 5 KUD sapi perah aktif yang berada di Kabupaten Semarang dan Kabupaten Boyolali. Hasil penelitian menunjukkan bahwa produksi hijauan pakan ternak tidak selalu kontinyu sepanjang tahun, terutama saat memasuki musim kemarau. Pengaturan pola penyediaan dan ketersediaan hijauan pakan akan mempengaruhi suplai pakan di kawasan peternakan sapi perah di Jawa Tengah. Berdasarkan hasil analisis SWOT, strategi yang diusulkan yaitu Introduksi teknologi pengawetan hijauan pakan dan limbah pertanian (silase, amoniase dan hay); Akselerasi
\end{abstract}


penguatan kualitas, materi, dan metode penyuluhan hijauan pakan; Pemanfaatan limbah pertanian; Koordinasi dengan Dinas terkait untuk ijin penggunaan lahan milik Perhutani; Fasilitasi dari Dinas/Instansi terkait dalam peningkatan teknologi dan manajerial peternak; Pengenalan dan pemahaman jenis-jenis hijauan pakan ternak berkualitas; dan Optimalisasi pemanfaatan limbah sapi sebagai pupuk kompos.

Kata kunci: Pakan hijauan, strategi pengembangan, sapi perah

\section{PENDAHULUAN}

Sebagai upaya akselerasi pengembangan peternakan berbasis kawasan, Pemerintah melalui Kementerian Pertanian telah mengeluarkan Kepmentan Nomor 43/Kpts/PD.410/1/2015 tentang Penetapan Kawasan Sapi Potong, Kerbau, Kambing, Sapi Perah, Domba dan Babi Nasional. Dalam Kepmentan tersebut, telah ditetapkan kawasan sapi perah meliputi Kabupaten Bandung dan Bandung Barat (Jawa Barat); Kabupaten Semarang dan Kota Salatiga (Jawa Tengah); dan Kabupaten Malang dan Kota Batu (Jawa Timur). Terbitnya Kepementan ini tentunya akan menjadi titik ungkit upaya akselerasi pembangunan industri susu dari hulu-hilir.

Provinsi Jawa Tengah merupakah wilayah potensial untuk pengembangan sapi perah, berkontribusi sekitar 25\% terhadap populasi sapi perah nasional. Wilayah pengembangan sapi perah yang ada di Jawa Tengah diantaranya Kabupaten Boyolali 61.887 ekor; Kabupaten Semarang 25.780 ekor; Kabupaten Klaten 5.486 ekor; Kota Salatiga 3.475 ekor; dan Kabupaten Banyumas 2.570 ekor (BPS 2017). Berdasarkan data tersebut, Kabupaten Boyolali dan Kabupaten Semarang merupakan sentra populasi sapi perah dan sentra produksi susu di Provinsi Jawa Tengah. Hal ini sejalan dengan penetapan kawasan sapi perah sesuai dengan Kepmentan Nomor 43 Tahun 2015.

Sapi perah sebagai penghasil produk utama susu, harus tercukupi kebutuhan pakannya baik dari segi kualitas dan kuantitas (hijauan dan konsentrat). Hal ini akan mempengaruhi terhadap jumlah produksi susu dan kualitas susu segar yang dihasilkan. Menurut Suhendra et al. (2015), imbangan hijauan dan konsentrat yang terbaik pengaruhnya terhadap kualitas susu adalah $60 \%$ berbanding $40 \%$. Ketersediaan hijauan sebagai salah satu komponen utama pakan diharapkan mampu memenuhi kebutuhan pakan semua populasi sapi perah yang ada pada kawasan tersebut baik induk laktasi, induk kering, sapi dara, dan pedet.

Produksi hijauan pakan ternak jumlahnya tidak selalu kontinyu sepanjang tahun, terutama saat memasuki musim kemarau. Saat memasuki musim kemarau, produksi hijauan akan menurun sehingga diperlukan mekanisme pengaturan pola hijauan pakan untuk mengantisipasi datangnya musim kemarau, dengan tetap menjaga kualitas hijauan pakannya. Pengaturan pola penyediaan, ketersediaan, dan vegetasi hijauan pakan yang dikembangkan akan mempengaruhi suplai pakan pada peternakan sapi perah. Selain itu, penyediaan pakan yang kontinyu telah diupayakan melalui teknologi pengolahan pakan, formulasi ransum, dan pembuatan complete feed melalui peningkatan pengetahuan peternak (Baba et al. 2011). Namun, peternakan sapi perah memiliki kondisi yang tidak sama antar wilayah (kondisi geografi dan demografi).

Agar produksi hijauan pakan ternak dapat kontinyu dan memenuhi kebutuhan kawasan sapi perah, maka diperlukan strategi pengembangan pola penyediaan hijauan pakan sesuai dengan spesifik lokasi. Peternak sapi perah pada kawasan 
peternakan dapat bertahan dan berkembang harus didukung dengan keberadaan kelembagaan, terutama koperasi yang bidang usaha utamanya mengelola produksi susu pada penyedia kebutuhan sarana usaha sapi perah (sapronak). Peternak skala rakyat dengan kepemilikan induk sapi kurang dari 5 ekor dan tidak memiliki cooling unit penyimpan susu sendiri. Skala kepemilikan sapi perah rakyat rata-rata $\leq 5$ ekor dan digunakan sebagai sambilan (Martindah \& Saptati 2008; Priyono \& Hapsari 2016).

Strategi pengembangan pola penyediaan hijauan pakan harus dilakukan secara sinergi antara peternak dan koperasi susu, sehingga produksi susu tetap optimal dan keberlanjutan di tingkat peternak serta kualitas susu yang dihasilkan juga memenuhi standar dari koperasi dan Industri Pengolahan Susu (IPS). Berdasarkan kondisi tersebut, diperlukan analisis pola penyediaan hijauan pakan dan strategi pengembangannya di lokasi kawasan peternakan sapi perah di Jawa Tengah.

Penelitian ini bertujuan untuk menganalisis pola penyediaan hijauan pakan dan strategi pengembangannya pada peternakan sapi perah di lokasi kawasan sapi perah di Jawa Tengah. Hasil penelitian diharapkan dapat digunakan sebagai bahan rekomendasi untuk pengembangan kawasan sapi perah lain maupun replikasi pada lokasi pengembangan kawasan sapi perah yang baru.

\section{MATERI DAN METODE}

Penelitian dilakukan di Kabupaten Semarang dan Kabupaten Boyolali Provinsi Jawa Tengah pada bulan November - Desember 2016 dengan metode survei terstruktur. Lokasi penelitian dipilih dengan metode purposive sampling dengan kriteria: (i) Lokasi penelitian merupakan sentra populasi sapi perah dan sentra produksi susu di Jawa Tengah; (ii) Lokasi penelitian ditetapkan sebagai salah satu lokasi kawasan peternakan sapi perah sesuai Kepmentan Nomor 43/Kpts/PD.410/1/2015; (iii) Pada lokasi penelitian terdapat KUD yang bergerak dalam usaha persusuan.

Pengambilan sampel dilakukan secara sensus pada 5 KUD sapi perah aktif yang berada di Kabupaten Semarang dan Kabupaten Boyolali, yang terdiri dari: KSU Wahyu Agung; Koperasi Andini Luhur; KUD Mojosongo; KUD Cepogo; dan KUD Musuk.

Data diperoleh dalam penelitian ini terdiri dari data primer dan sekunder. Data primer diperoleh dari hasil pengamatan, observasi dan wawancara langsung dengan responden. Sementara itu, data sekunder diperoleh dari instansi terkait, yaitu KUD, Badan Pusat Statistik (BPS) dan SKPD terkait di Kabupaten Semarang dan Kabupaten Boyolali.

Analisis data dilakukan dengan menggunakan pendekatan analisis deskriptif terkait pola distribusi pemberian pakan hijauan sepanjang tahun pada masing-masing KUD serta melalui tabulasi dan pembuatan grafik. Sementara itu, strategi pengembangan dianalisis menggunakan pendekatan analisis SWOT. Analisis SWOT digunakan untuk membandingkan antara faktor internal (Strength dan Weakness) dengan faktor eksternal (Opportunity dan Threats). Analisis faktor internal dan faktor eksternal digunakan untuk menentukan strategi agar hijauan pakan peternakan sapi perah dapat tersedia secara kontinu pada lokasi kawasan di Jawa Tengah. 


\section{HASIL DAN PEMBAHASAN}

\section{Pola penyediaan pakan hijauan di kawasan sapi perah}

Kebutuhan hijauan pakan pada kawasan sapi perah di Jawa Tengah ditentukan oleh jumlah populasi sapi perah yang ada. Pengaturan penyediaan hijauan pakan tidak sama untuk setiap ekornya, tergantung dari struktur populasinya. Sapi muda/dara dan anak, masing-masing memiliki kebutuhan hijauan pakan sebanyak 0,5 dan 0,25 dari jumlah pakan induknya. Dengan demikian, semakin tinggi jumlah populasi sapi perah pada lokasi kawasan maka harus didukung dengan daya dukung lahan hijauan makanan ternak yang memadai. Pola penyediaan pakan hijauan sapi perah di lokasi yang diamati secara terinci disajikan pada Tabel 1.

Hasil pengamatan menunjukkan bahwa ada kecenderungannya pada saat musim kemarau (bulan 8-10) terjadi defisit rumput gajah (KUD Wahyu Agung, Andini Luhur dan Musuk) sehingga pakan hijauan dikombinasikan dengan rumput lapang maupun jerami padi yang hal tersebut akan berpengaruh terhadap penurunan produksi susu. Kondisi demikian diperlukan strategi pengganti keberadaan rumput gajah dalam antisipasi penurunan produksi susu di musim kemarau. Substitusi dengan jerami jagung cukup bagus tetapi pada lokasi yang spesifik (khususnya KUD Mojosongo, Cepogo dan Musuk). Rumput gajah sebagian besar diperoleh dari kebun milik sendiri yang diberikan rata-rata sebanyak $40 \mathrm{~kg} / \mathrm{ekor} / \mathrm{hari}$. Pemberian rumput yang diberikan pada sapi dengan cara dicacah akan mempengaruhi konsumsi pakan dan penyerapan nutrien pakan (Novianti et al. 2014). Rumput lapang diperoleh dengan memotong rumput secara cut and carry dan diberikan pada sapi 15-20 kg/ekor/hari saat puncak musim kemarau. Sementara itu, untuk memenuhi kekurangannya ditambahkan jerami padi mencapai 20 kg/ekor/hari. Sebagian besar jerami padi diperoleh dari wilayah Kabupaten Magelang.

Di Kabupaten Semarang dan Boyolali, rumput gajah menjadi andalan utama untuk pemenuhan hijauan untuk sapi. Anggota KUD Wahyu Agung dan KUD Musuk sebagian besar menggunakan rumput gajah sebagai sumber hijauan pakan. Saat musim kemarau, peternak akan mengkombinasikan dengan pemberian rumput lapang dan jerami padi sebagai pakan sapi dikarenakan produksi rumput gajah menurun. Pemberian jerami padi hendaknya dilakukan perlakuan fermentasi. Fermentasi jerami padi dengan substrat yang berbeda berpengaruh terhadap kualitas jerami padi fermentasi (Zakaria et al. 2013).

Dengan mengamati pola penyediaan pakan oleh masing-masing KUD, maka KUD Cepogo memiliki pola penyediaan yang lebih baik dari KUD lainnya. Selain kontinu jumlah pemberiannya, KUD Cepogo juga menerapkan kombinasi konsumsi legume untuk sapi perah yang memiliki kualitas protein lebih baik dibandingkan dengan jerami seperti Indigofera sp. Rumput gajah yang berlebih pada musim hujan dapat dijadikan alternatif konsumsi di musim kemarau dengan cara mengolahnya menjadi silase atau hay. 
Tabel 1. Pola penyediaan hijauan pakan pada kawasan sapi perah

\begin{tabular}{|c|c|c|c|c|c|c|c|c|c|c|c|c|}
\hline \multirow{2}{*}{ Jenis hijauan } & \multicolumn{12}{|c|}{ Bulan ke- $(\%)$} \\
\hline & 1 & 2 & 3 & 4 & 5 & 6 & 7 & 8 & 9 & 10 & 11 & 12 \\
\hline \multicolumn{13}{|c|}{ KSU Wahyu Agung - Kabupaten Semarang } \\
\hline Rumput gajah & 100 & 100 & 100 & 100 & 100 & 100 & 100 & 50 & 50 & 50 & 50 & 50 \\
\hline Rumput lapang & 0 & 0 & 0 & 0 & 0 & 0 & 0 & 30 & 30 & 30 & 30 & 30 \\
\hline Jerami padi & 0 & 0 & 0 & 0 & 0 & 0 & 0 & 20 & 20 & 20 & 20 & 20 \\
\hline \multicolumn{13}{|c|}{ Koperasi Andini Luhur - Kabupaten Semarang } \\
\hline Rumput gajah & 80 & 80 & 80 & 80 & 80 & 80 & 80 & 80 & 50 & 50 & 50 & 50 \\
\hline Rumput lapang & 0 & 0 & 0 & 0 & 0 & 0 & 0 & 0 & 25 & 25 & 25 & 25 \\
\hline Jerami padi & 0 & 0 & 0 & 0 & 0 & 0 & 0 & 0 & 25 & 25 & 25 & 25 \\
\hline Jerami jagung & 20 & 20 & 20 & 20 & 20 & 20 & 20 & 20 & 0 & 0 & 0 & 0 \\
\hline \multicolumn{13}{|c|}{ KUD Mojosongo - Kabupaten Boyolali } \\
\hline Rumput gajah & 50 & 50 & 50 & 50 & 50 & 50 & 50 & 50 & 50 & 50 & 50 & 50 \\
\hline Jerami padi & 25 & 25 & 25 & 25 & 25 & 25 & 25 & 25 & 25 & 25 & 25 & 25 \\
\hline Jerami jagung & 25 & 25 & 25 & 25 & 25 & 25 & 25 & 25 & 25 & 25 & 25 & 25 \\
\hline \multicolumn{13}{|c|}{ KUD Cepogo - Kabupaten Boyolali } \\
\hline Rumput gajah & 70 & 70 & 70 & 70 & 70 & 70 & 70 & 70 & 70 & 70 & 70 & 70 \\
\hline Legume & 20 & 20 & 20 & 20 & 20 & 20 & 20 & 20 & 20 & 20 & 20 & 20 \\
\hline Jerami jagung & 10 & 10 & 10 & 10 & 10 & 10 & 10 & 10 & 10 & 10 & 10 & 10 \\
\hline \multicolumn{13}{|c|}{ KUD Musuk - Kabupaten Boyolali } \\
\hline Rumput gajah & 100 & 100 & 100 & 100 & 100 & 100 & 50 & 50 & 50 & 50 & 100 & 100 \\
\hline Jerami padi & 0 & 0 & 0 & 0 & 0 & 0 & 50 & 50 & 50 & 50 & 0 & 0 \\
\hline
\end{tabular}




\section{Performa produksi susu dan struktur populasi sapi perah}

Lokasi penelitian yang diambil di Kabupaten Semarang dan Kabupaten Boyolali Provinsi Jawa Tengah merupakan lokasi kawasan pengembangan sapi perah. Penguatan kelembagaan koperasi susu dalam kawasan cukup efektif dalam menunjang perkembangan populasi sapi perah dan produksi susu (Priyono \& Priyanti 2015). Di lokasi dimaksud, sapi dipelihara oleh peternak yang menjadi anggota koperasi (KUD). Peternak anggota menjual susu ke KUD, dan KUD menyediakan fasilitas untuk membantu kebutuhan anggota diantaranya akses penjualan konsentrat, pelayanan kesehatan, pembinaan SDM, dan pelayanan introduksi teknologi dalam mempertahankan kualitas susu. Pengamatan dilakukan pada koperasi aktif dan yang memiliki anggota aktif di Kabupaten Semarang dan Kabupaten Boyolali.

Dalam pemeliharaan sapi perah, hijauan pakan ternak memiliki urgensi yang penting dalam menentukan kualitas susu yang dihasilkan. Kebutuhan hijauan pakan sebanyak 10\% dari bobot badan induk diupayakan dapat terpenuhi, sehingga mampu menghasilkan performa produksi susu dengan kualitas sesuai dengan yang disyaratkan oleh koperasi. Susu segar yang disetor/dijual oleh anggota ke koperasi akan diuji kualitas susunya menggunakan lactoscan. Hal ini dilakukan supaya susu segar tersebut memenuhi kriteria dari Industri Pengolahan Susu (IPS).

Berdasarkan 5 koperasi aktif yang diamati, terdapat 5 koperasi yang mampu menghasilkan susu dari anggota rata-rata > dari 20.000 liter/hari. Besaran produksi susu sangat dipengaruhi oleh jumlah induk laktasi. Struktur populasi sapi perah di lokasi kawasan peternakan sapi perah di Jawa Tengah dapat dilihat pada Tabel 2.

Tabel 2. Struktur populasi sapi perah di lokasi kawasan

\begin{tabular}{lcccc}
\hline \hline & Populasi & \multirow{2}{*}{$\begin{array}{c}\text { Jumlah susu } \\
\text { disetor } \\
\text { KUD }\end{array}$} & \multicolumn{2}{c}{ Persentase struktur populasi } \\
\cline { 5 - 5 } & betina (ekor) & (liter/hari) & Induk & $\begin{array}{c}\text { Muda dan } \\
\text { anak }\end{array}$ \\
\hline $\begin{array}{l}\text { KSU Wahyu } \\
\text { Agung }\end{array}$ & 6.336 & 22.000 & 70,00 & 30,00 \\
$\begin{array}{l}\text { Koperasi Andini } \\
\text { Luhur }\end{array}$ & 5.532 & 30.000 & 76,93 & 23,07 \\
KUD Mojosongo & 7.315 & 35.000 & 70,00 & 30,00 \\
KUD Cepogo & 1.250 & 12.000 & 51,72 & 48,28 \\
KUD Musuk & 4.200 & 28.000 & 60,00 & 40,00 \\
\hline
\end{tabular}

Tabel 2 menunjukkan bahwa struktur populasi yang didominasi oleh induk akan mampu memberikan setoran susu ke KUD yang relatif lebih besar dibandingkan dengan yang persentase induknya lebih kecil. Secara parsial induk laktasi dan jumah ternak berpengaruh positif terhadap produksi susu per peternak (Astuti et al. 2010). Peternak yang masuk anggota Koperasi Andini Luhur memiliki struktur populasi induk (76,93\%), artinya dengan asumsi 100 ekor sapi perah yang dipelihara, sebanyak 77 ekor sapi mampu menghasilkan produksi susu. Struktur populasi induk (sapi laktasi) populasi ke-2 adalah di KSU Wahyu Agung dan KUD Mojosongo sebesar $70 \%$. 
Adapun untuk peternak anggota yang masuk anggota KUD Cepogo, struktur populasi induk terendah sebesar 51,72\%. Idealnya persentase induk yang berproduksi minimal 60\%, sehingga kontribusi penjualan usaha akan mampu menutup biaya usaha untuk sapi yang sedang tidak berpoduksi, yaitu sapi muda dan pedet. Pada pemeliharaan induk yang rendah, bisa terjadi sampai dalam kondisi kering kandang semua, sehingga tidak ada penghasilan susu yang diperoleh peternak (Priyanto et al. 2015). Pada KUD Cepogo dengan struktur populasi sapi muda dan anak sebesar 48,28\% (khususnya anak betina) jika dibesarkan dengan baik dan diberikan pakan yang tercukupi secara kuantitas dan diseleksi berdasarkan kualitas induknya, maka akan berpotensi menghasilkan indukan berproduksi susu tinggi. Sementara itu, untuk sapi muda jantan atau anak jantan dapat dikeluarkan/dijual untuk mengurangi beban biaya pakan dan biaya produksi.

KUD Mojosongo yang berlokasi di Kabupaten Boyolali merupakan koperasi yang mampu menghasilkan susu segar sebanyak kurang lebih 35.000 liter/hari. Adapun di Kabupaten Semarang, Koperasi Andini Luhur mampu menghasilkan produksi susu segar sebanyak kurang lebih 30.000 liter/hari dan terendah adalah di KUD Cepogo 12.000 liter/hari. Jika dibuatkan matriks share produksi susu harian, diantara 5 koperasi aktif, KUD Mojosongo memiliki kontribusi penyuplai susu harian sebesar 27,56\% dan Koperasi Andini Luhur berkontribusi sebesar 23,62\%. Secara terinci pemetaan produksi susu segar dimaksud, dapat dapat dilihat pada Gambar 1.

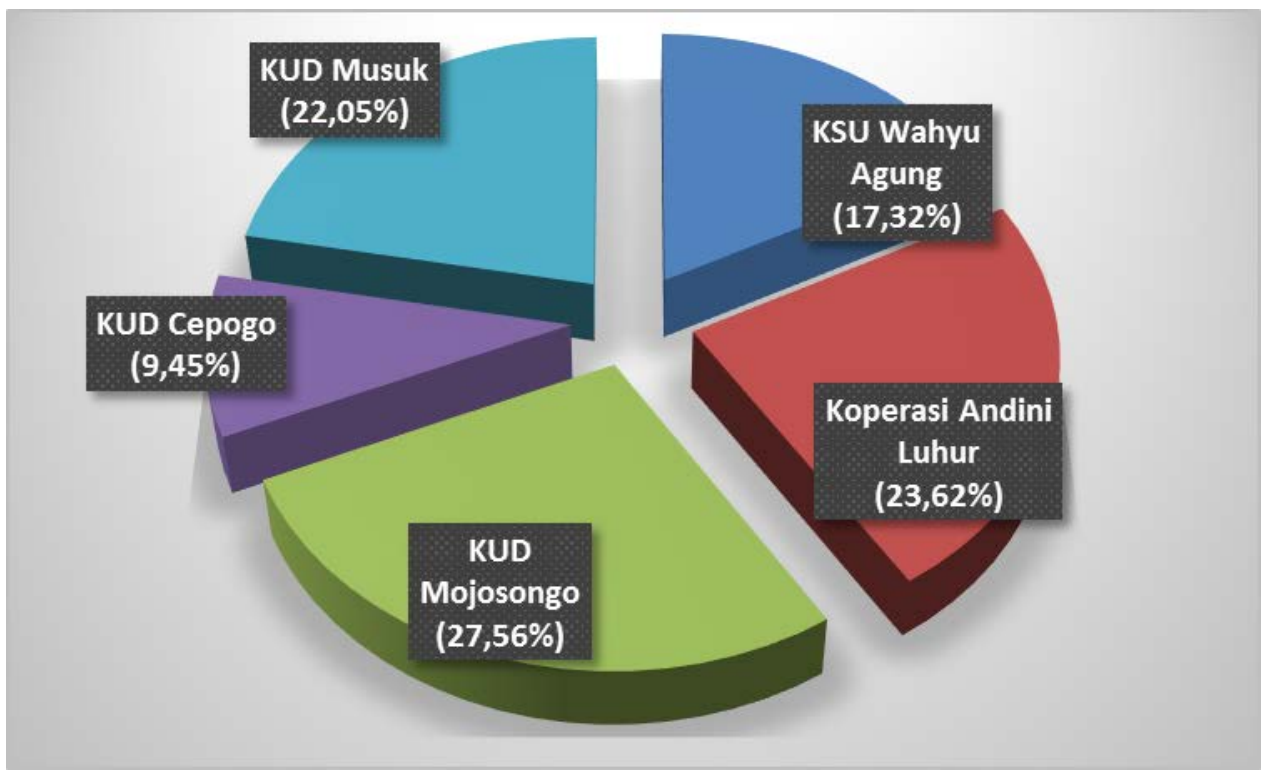

Gambar 1.Hasil pemetaan jumlah produksi susu segar di Kabupaten Semarang dan Kabupaten Boyolali

Besaran produksi susu selain dipengaruhi oleh struktur populasi induk, faktor pakan menjadi hal yang harus diperhatikan untuk menjaga kontinuitas produksi susu. Pakan sapi perah berasal dari pakan hijauan dan konsentrat. Kedua jenis pakan ini harus dapat dikontrol pemberiannya sehingga induk sapi laktasi yang sedang 
berproduksi tersebut tercukupi kebutuhan pakannya baik dari aspek kuantitas dan kualitas.

\section{Strategi pengembangan penyediaan pakan hijauan}

Berdasarkan pola penyediaan hijauan pakan yang saat ini dilakukan di koperasi aktif yang diamati, diperlukan strategi pengembangan hijauan pakan. Dalam menentukan strategi dimaksud, diperlukan identifikasi faktor internal (kekuatan dan kelemahan) dan faktor eksternal (peluang dan ancaman) terkait pengembangan penyediaan hijauan pakan di kawasan peternakan sapi perah di Jawa Tengah. Gambar 2.

\section{Weakness (Kelemahan):}

1. Keterbatasan lahan untuk penanaman hijauan makanan ternak.

2. Hijauan yang berkualitas belum terpenuhi kebutuhannya saat musim kemarau.

3. Keterbatasan informasi peternak mengenai lahan yang dapat dimanfaatkan untuk penanaman hijauan (bersama dengan tanaman pangan)

4. Kurang termanfaatkannya limbah (kotoran) ternak untuk penanaman hijauan

\section{Strength (Kekuatan):}

1. Saat musim hujan, ketersediaan hijauan cukup melimpah untuk pakan.

2. Anggota koperasi sebagian besar memiliki lahan yang ditanami Rumput Gajah/Rumput Raja.

3. Program penyuluhan terkait pakan ternak sering disampaikan oleh KUD/Dinas kepada anggota koperasi

4. Keberadaan dan kemampuan petugas penyuluh lapang

\section{Threat (Ancaman):}

1. Musim kemarau berpengaruh terhadap penurunan produksi hijauan.

2. Bertambahnya pemukiman penduduk berpengaruh pada terbatasnya lahan untuk penanaman hijauan

3. Kemampuan penguasaan teknologi dan manajerial hijauan peternak masih rendah

4. Kurangnya inisiatif peternak untuk menambah luas lahan bagi ketersediaan hijauan (bersama dengan tanaman pangan).

\section{Opportunities (Peluang):}

1. Saat musim kemarau mengambil rumput lapang dari rawa pening dan sekitarnya.

2. Ketersediaan daun/rumput yang ada di lahan/lapangan fasilitas umum masyarakat.

3. Ketersediaan jerami padi untuk tambahan pakan dengan hanya mengeluarkan uang transport.

4. Menebas jerami jagung untuk pakan hijauan alternatif berdasarkan luasan.

5. Penggunaan ijin lahan kosong milik pemerintah (perhutani) untuk dimanfaatkan sebagai lahan penanaman hijauan (Permentan tentang Kemitraan)

Gambar 2. Matriks analisis SWOT penyediaan hijauan pakan sapi perah

Melalui identifikasi analisis SWOT dihasilkan empat alternatif strategi yaitu: (i) alternatif strategi SO (strategi memaksimalkan kekuatan untuk memanfaatkan 
peluang); (ii) alternatif strategi WO (strategi meminimalkan kelemahan untuk memanfaatkan peluang); (iii) alternatif strategi ST (strategi yang menggunakan kekuatan untuk mengatasi ancaman); dan (iv) alternatif strategi WT (strategi yang meminimalkan kelemahan dan menghindari ancaman). Strategi yang diusulkan berdasarkan hasil analisis SWOT pengembangan hijauan pakan ternak di lokasi kawasan peternakan sapi perah di Jawa Tengah yaitu:

\section{a. Strategi SO (strength-opportunities)}

1. Introduksi teknologi pengawetan hijauan pakan dan limbah pertanian (silase, amoniase dan hay) saat hijauan melimpah pada musim penghujan.

Pembuatan amoniasi limbah pertanian sangat bermanfaat bagi para peternak pada saat kekurangan pakan atau musim kemarau (Pawerel et al. 2016). Teknologi pengawetan secara basah (silase) terhadap hijauan pakan ternak sangat direspon baik oleh para peternak (Mansyur et al. 2012). Lebih lanjut menurut Dianita et al. (2014), bahwa teknologi pengolahan silase hijauan pakan (legum) dan limbah menjadi upaya pengawetan sekaligus peningkatan kualitas nutrisi hijauan pakan dari limbah pertanian.

2. Akselerasi penguatan kualitas, materi dan metode penyuluhan terkait pengembangan pakan hijauan pada peternak.

Pendekatan penyuluhan agar efektif dapat menggunakan pendekatan partisipatif dengan mengutamakan kebutuhan partisipan penyuluhan dan dilakukan secara berkelanjutan (Amanah 2007). Penggunaan metode penyuluhan yang tepat sesuai dengan kebutuhan petani akan berdampak pada efektivitas dan efisiensi penyelenggaraan penyuluhan, serta mempercepat proses adopsi inovasi teknologi pertanian (Permentan No 52 Tahun 2009). Penerapan metode penyuluhan secara tepat, rutin, dan berkala akan mampu mengakselerasi adopsi berbagai teknologi sehingga mampu mendorong keberhasilan baik dari pengetahuan, sikap, keterampilan, peningkatan produksi dan replikasi (Musyadar et al. 2014).

3. Pemanfaatan limbah pertanian sebagai alternatif hijauan

Wilayah Kabupaten Semarang memiliki potensi limbah tanaman pangan seperti jerami padi, jagung, ketela pohon yang dapat dimanfaatkan sebagai pakan ternak dan potensi tanaman hijauan pakan ternak seperti rumput lapangan, rumput unggul (Mulyo et al. 2012).

\section{b. Strategi WO (weakness-opportunities)}

1. Melakukan koordinasi dengan Dinas terkait untuk ijin penggunaan lahan milik Perhutani.

Pemanfaatan lahan untuk penanaman hijauan untuk peternak diijinkan sepanjang tidak menebang pohon dan menguasai lahan sebagaimana tertuang dalam Peraturan Menteri LHK Nomor P81/MenLHK/Setjen/KUM.1/10/2016. Hal ini diperkuat dengan Peraturan Daerah Kabupaten Semarang Nomor 6 Tahun 2011 tentang Rencana Tata Ruang Wilayah Kabupaten Semarang Tahun 2011-2031. Kawasan tertentu dapat dimanfaatkan untuk kegiatan pemeliharaan, pembiakan dan penyediaan pakan serta kegiatan industri pengolahan pakan dan hasil ternak 
secara permanen. Pemilihan lokasi diutamakan pada tanah yang tidak produktif dan terpisah dari lahan pertanian penduduk sekitarnya.

2. Pengadaan akomodasi untuk pengangkutan hijauan yang cukup jauh dari kelompok ternak.

\section{c. Strategi ST (strength-threat)}

1. Fasilitasi dari Dinas/Instansi terkait dalam peningkatan teknologi dan manajerial pengembangan hijauan bagi peternak.

Intensifikasi usaha dan tatalaksana pemberian hijauan pada ternak, dapat dilakukan melalui pengembangan teknik-teknik pengawetan kering (hay) dan segar (silase), serta pemanfaatan sumber hijauan lain untuk menjamin persediaan pakan utama dan pengembangan teknologi pemanfaatan limbah seperti jerami padi dan jagung (Amar 2008). Teknologi pengolahan pakan, formulasi ransum, dan pembuatan complete feed sangat diperlukan peternak melalui penguatan kelembagaan peternak. Daerah nonsentra membutuhkan pengolahan dan pengawetan pakan, serta teknologi pembuatan complete feed yang dikembangkan melalui penguatan kelembagaan peternak (Baba et al. 2011).

2. Perluasan areal lahan hijauan pakan ternak secara berkelanjutan sesuai kebutuhan.

Makin luas hijauan makan ternak semakin meningkatkan motivasi beternak, sebaliknya makin sempit lahan pertanian semakin rendah motivasi beternak, sehingga hal ini akan mendorong peternak untuk giat bekerja pada usaha sapi potong (Luanmase et al. 2011).

\section{d. Strategi WT (weakness-threat)}

1. Memberikan pengenalan dan pemahaman jenis-jenis hijauan pakan ternak yang berkualitas dalam antisipasi pada musim kemarau.

Pengenalan beberapa pilihan jenis hijauan pakan ternak baik rumput maupun legume akan menjadi alternatif bagi peternak sapi perah sesuai dengan spesifik lokasi. Beberapa jenis hijauan yang dapat diintroduksikan diantaranya rumput signal/rumput BD (Brachiaria decumbens), gamal (glirisidae), dan Indigofera (indigofera sp). Indigofera dapat dimanfaatkan secara optimal sebagai tanaman bermutu tinggi yang dapat dimanfaatkan sebagai salah satu sumber hijauan pakan ternak secara kontinyu (Arniaty et al. 2015).

2. Optimalisasi pemanfaatan limbah ternak sebagai pupuk kompos untuk areal lahan hijauan pakan ternak

Limbah ternak baik feses dan urine dapat dimanfaatkan sebagai pupuk kompos untuk tanaman. Beberapa faktor yang mempengaruhi optimalisasi pemanfaatan limbah ternak sebagai pupuk kompos, yaitu sistem usaha tani ternak; keterampilan peternak dalam pengolahan limbah; bahan baku pengolahan limbah; dan pemasaran hasil produksi (Risal \& Baba 2014). Lebih lanjut menurut Pancapalaga (2011), pupuk cair dengan 100\% menggunakan bahan baku limbah ternak mempunyai kandungan $\mathrm{N}, \mathrm{P}$ dan $\mathrm{K}$ 
yang optimal. Pemanfaatan biogas dan pupuk cair, mampu memberikan keuntungan tambahan bagi peternak (Adityawarman et al. 2015).

\section{KESIMPULAN}

Pola penyediaan hijauan pakan ternak untuk sapi perah sebagian besar bergantung pada ketersediaan rumput gajah. Sebagian anggota koperasi mengkombinasikan dengan pemberian rumput lapang, legume, dan limbah tanaman pangan (jerami padi dan jerami/tebon jagung). Kombinasi rumput gajah dan legume secara kontinu menjadi pola yang lebih baik dibanding pemberian rumput gajah yang cukup banyak namun ketika musim kemarau terjadi kekurangan. Saat produksi rumput gajah menurun pada musim kemarau, persentase pemberian rumput lapang dan limbah tanaman pangan akan meningkat. Berdasarkan hasil analisis. Strategi diarahkan pada upaya kontinuitas produksi hijauan untuk dapat memenuhi kebutuhan pakan berdasarkan populasi saat ini dan prediksi beberapa tahun kedepan. Pengolahan pakan hijauan (silase dan hay) saat produksi berlebih serta pengembangan alternatif lain (penanaman leguminosa) yang bisa berkembang di daerah setempat. Selain itu, pembinaan peternak secara intensif dalam program pengolahan pakan hijauan sangat dimungkinkan karena didukung oleh petugas penyuluh dan sarana yang tersedia.

\section{UCAPAN TERIMA KASIH}

Penulis mengucapkan terima kasih pada Dinas Peternakan dan Kesehatan Hewan Provinsi Jawa Tengah dan Ketua KUD beserta anggota yang telah membantu dalam pelaksanaan pengamatan, observasi dan pengambilan data.

\section{DAFTAR PUSTAKA}

Adityawarman AC, Salundik, Lucia. 2015. Pengolahan limbah ternak sapi secara sederhana di Desa Pattalassang Kabupaten Sinjai Sulawesi Selatan. J Ilmu Produksi dan Teknologi Hasil Peternakan. 3:171-177.

Amanah S. 2007. Makna penyuluhan dan transformasi perilaku manusia. J Penyuluhan Desember. 4:63-67.

Amar AL. 2008. Strategi penyediaan pakan hijauan untuk pengembangan sapi potong di Sulawesi Tengah. Dalam: Sani Y, Martindah E, Nurhayati, Puastuti W, Sartika T, Parede L, Anggraeni A, Natalia L, penyunting. Prosiding Seminar Nasional Teknologi Peternakan dan Veteriner. Bogor (Indonesia): Pusat Penelitian dan Pengembangan Peternakan. hlm. 172-179.

Arniaty S, Rizmi A, Ubaidatussalihat. 2015. Daya tahan tanaman Indigofera sp. yang ditanam pada lahan kritis pada musim kering sebagai sumber pakan ternak ruminansia. J Ilmiah Peternakan. 3:44-47.

Astuti M, Widiati R, Suranindyah YY. 2010. Efisiensi produksi usaha sapi perah rakyat (studi kasus pada peternak anggota koperasi usaha peternakan dan pemerahan sapi perah Kaliurang, Sleman, Yogyakarta). Buletin Peternakan. 34:64-69.

Baba S, Muktiani A, Ako A, Dagong MIA. 2011. Keragaman dan kebutuhan teknologi pakan peternak sapi perah di Kabupaten Enrekang. Media Peternakan. 34:146-154. 
[BPS] Badan Pusat Statistik. 2017. Statistik Indonesia Tahun 2017. Jakarta (Indonesia): Badan Pusat Statistik.

Dianita R, Rahman A, Syarifuddin H, Syafwan, Zubaidah. 2014. Perbaikan pakan hijauan melalui introduksi legum indigofera dan pembuatan silase legum-jerami jagung pada kelompok tani ternak di Kecamatan Pelayangan. J Pengabdian Pada Masyarakat. 29:76-79.

Luanmase CM, Nurtini S, Haryadi FT. 2011. Analisis motivasi beternak sapi potong bagi peternak lokal dan transmigran serta pengaruhnya terhadap pendapatan di Kecamatan Kairatu, Kabupaten Seram Bagian Barat. Buletin Peternakan. 35:113123.

Martindah E, Saptati RA. 2008. Peran dan upaya koperasi peternak sapi perah dalam meningkatkan kualitas susu di Jawa Barat. Prosiding Semiloka Nasional Prospek Industri Sapi Perah menuju Perdagangan Bebas 2020. Bogor (Indonesia): Pusat Penelitian dan Pengembangan Peternakan. hlm. 476-483.

[Kepmentan] Keputusan Menteri Pertanian. 2015. Kepmentan Nomor 43/Kpts/ PD.410/1/2015 tentang Penetapan Kawasan Sapi Potong, Kerbau, Kambing, Sapi Perah, Domba dan Babi Nasional. Jakarta (Indonesia): Kementerian Pertanian.

Mansyur T, Dhalika, Islami RZ. 2012. Implementasi strategi dan teknologi kecukupan pakan sepanjang tahun untuk penyembangan peternakan sapi perah di Desa Sukawargi dan Cidatar Kecamatan Cisurupan Kabupaten Garut. Jurnal Aplikasi Ipteks untuk Masyarakat. 1:64-73.

Mulyo IT, Marzuki S, Santoso SI. 2012. Analisis kebijakan pemerintah mengenai budidaya sapi potong di Kabupaten Semarang. Anim Agric J. 1:266-277.

Musyadar A, Isu1 EYO, Wibowo S. 2014. Hubungan metode penyuluhan pertanian dengan tingkat keberhasilan pendekatan PTT padi sawah di Kecamatan Wolowaru, Kabupaten Ende, Provinsi Nusa Tenggara Timur. Jurnal Pertanian. 5:58-72.

Novianti J, Purwanto BP, Atabany A. 2014. Efisiensi produksi susu dan kecernaan rumput gajah (Pennisetum purpureum) pada sapi perah $\mathrm{FH}$ dengan pemberian ukuran pemotongan yang berbeda. Jurnal Ilmu Produksi dan Teknologi Hasil Peternakan. 2:224-230.

[Pemda Semarang] Pemerintah Daerah Kabupaten Semarang. 2011. Peraturan Daerah Kabupaten Semarang Nomor 6 Tahun 2011 Tentang Rencana Tata Ruang Wilayah Kabupaten Semarang Tahun 2011-2031. Semarang (Indonesia): Pemerintah Daerah Kabupaten Semarang.

[Permen LHK] Peraturan Menteri Lingkungan Hidup dan Kehutanan Republik Indonesia. 2016. Peraturan Menteri Lingkungan Hidup dan Kehutanan Republik Indonesia Nomor P81/MenLHK/Setjen/KUM.1/10/2016 tentang Kerjasama Penggunaan dan Pemanfaatan Kawasan Hutan untuk Mendukung Ketahanan Pangan. Jakarta (Indonesia): Kementerian Lingkungan Hidup dan Kehutanan.

Priyanto D, Nasrullah, Isbandi. 2015. Pengembangan usaha ternak sapi perah rakyat di Pulau Jawa (profil, masalah, solusi). Jakarta (Indonesia): IAARD Press.

Pancapalaga W. 2011. Pengaruh rasio penggunaan limbah ternak dan hijauan terhadap kualitas pupuk cair. GAMMA. 7:61-68.

Pawerel FR, Sonbait LY. 2016. Alternatif penyediaan pakan dengan penerapan budidaya hmt organik, teknologi pengolahan hijauan dan limbah pertanian pada sentra produksi sapi potong di Kabupaten Manokwari. J Udayana Mengabdi. 15:24-29. 
Priyono, Priyanti A. 2015. Penguatan kelembagaan koperasi susu melalui pendekatan pengembangan kawasan peternakan nasional. Wartazoa. 25:85-94.

Priyono, Hapsari AAR. 2016. Komparasi analisis kelayakan usaha sapi perah rakyat pada non kawasan dan kawasan sapi perah di Jawa Tengah. Prosiding Seminar Nasional Kebangkitan Peternakan. Semarang (Indonesia): Magister Ilmu Ternak Universitas Diponegoro. hlm. 353-364.

Risal M, Baba S. 2014. Strategi pemanfaatan limbah ternak sapi sebagai solusi peningkatan kesejahteraan petani di Kabupaten Maros. Prosiding Seminar Nasional \& Workshop Optimalisasi Sumberdaya Lokal pada Peternakan Rakyat Berbasis Teknologi. Bogor (Indonesia): Pusat Penelitian dan Pengembangan Peternakan. hlm. 321-328.

Suhendra D, Anggiati GT, Sarahm S, Nasrullah AF, Thimoty A, Utama DWC. 2015. Tampilan kualitas susu sapi perah akibat imbangan konsentrat dan hijauan yang berbeda. J Ilmu-Ilmu Peternakan. 25:42-46.

Zakaria Y, Novita CI, Samadi. 2013. Efektifitas fermentasi dengan sumber substrat yang berbeda terhadap kualitas jerami padi. Agript. 13:22-25. 